2 Ritchie DBC, Jennings LC, Lynn KL, Bailey RR, Cook HB. Clostridium difficile-associated colitis: cross-infection in predisposed patients with renal failure. NZ Med f 1982;95:265-7. oxton IR. Detection and isolation of Clostridium difficile. European 7 oumal of Chemotherapy and Antibiotics 1982;2:123-8

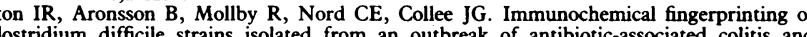

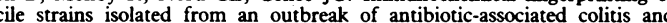
diarrhoea. $\mathcal{F}$ Med Microbiol 1984;17:317-24.

5 Larson $\mathrm{HE}$, Price AB, Honour $\mathrm{P}$, Borriello SP. Clostridium difficile and the aetiology of pseudomembranous colitis. Lancet 1978; i: 1063-6.

(Accepted 22 October 1985)

University Department of Medicine and Medical Renal Unit, Royal Infirmary, Edinburgh EH3 9YW

ALLAN D CUMMING, MB, MRCP, lecturer

BRIAN J THOMSON, MB, MRCP, registrar

Department of Bacteriology, University of Edinburgh Medical School, Edinburgh EH8 9AG

JACQUELINE SHARP, BSC, research student

IAN R POXTON, BSC, PHD, lecturer

ANDREW G FRASER, BSC, MD, senior lecturer

Correspondence to: Dr Fraser.

\section{Retention of urine in occult anorectal herpes}

Urinary retention in patients with symptomatic anogenital herpes simplex infection is well documented. We report two cases of micturition difficulties in patients with occult anorectal infection.

\section{Case reports}

Case 1-A 23 year old man was transferred to the Whittington Hospital from HM prison with acute urinary retention which necessitated catheterisation. He gave a five day history of dysuria without urethral discharge and denied anal discomfort or discharge. The anus and perianal area appeared normal but proctoscopy showed a severely inflamed rectal mucosa. Both rectal and urethral smears contained multiple polymorphs but no organisms on Gram staining and were negative on culture for Neisseria gonorrhoeae and Chlamydia trachomatis. The rectal culture was, however, positive for herpes simplex virus. The catheter was removed after 24 hours but was reinserted because of continued retention. He required catheterisation for a further nine days, after which he managed to pass urine without further difficulty. The patient subsequently absconded from hospital and was not seen for follow up.

Case 2-A 30 year old homosexual man attended the department of genitourinary medicine on 6 April with a sore throat, headache, and enlarged cervical lymph nodes. One week later he developed perianal discomfort. Examination showed two small, dry perianal vesicles but no inguinal lymphadenopathy. Culture of the vesicles for herpes simplex virus was negative. Initial serological studies yielded a positive treponema haemagglutination test result and positive rapid plasma reagin test at a titre of $1 / 256$, and so treatment for secondary syphilis was started in the form of procaine penicillin injections daily for 15 days. On 18 April he complained of difficulty in passing urine over the previous 48 hours but denied anal discomfort or discharge. The external genitalia and perianal area appeared normal but the bladder was enlarged to the level of the umbilicus. There was no sensory loss and the bulbocavernosus reflex was present. The rectal mucosa looked inflamed and Gram staining showed multiple polymorphs but no organisms. Cultures were negative for $N$ gonorrhoeae and herpes simplex virus. He was admitted to hospital and continued to have difficulty in initiating micturition with a lack of sensation. The stream was very weak and he managed to pass only small amounts of urine at a time. Bethanechol chloride by mouth was prescribed with some improvement. Optimal response was achieved when the dose was increased to $20 \mathrm{mg}$ four times a day. The medication needed to be continued for 12 days to control his symptoms. On 30 April repeat proctoscopy showed a normal rectal mucosa. Rectal swabs on this occasion were negative for $N$ gonnorrhoaea but positive for herpes simplex virus.

\section{Comment}

Herpes simplex virus infection of the anorectum in homosexual men was first described by Astruc in 1736. It is now considered to be the commonest cause of non-gonococcal proctitis in male homosexuals. ${ }^{1}$ Asymptomatic herpes proctitis has been mentioned recently, though severe pain, tenesmus, and rectal discharge usually dominate the clinical picture. ${ }^{2}$ Urinary retention associated with acute anogenital herpes is well described; however, in these cases there were easily recognisable features of herpetic infection. ${ }^{34}$

We report what appear to be the first documented cases of urinary retention and micturition difficulties associated with occult herpes simplex virus infection. Evidence of anorectal infection was suspected and was deliberately pursued, repeatedly in the second patient.

The development of urinary retention in some patients associated with paraesthesia of the second and third sacral dermatomes, neuralgia, constipation, and impotence has suggested a lumbosacral radiculomyelopathy or a localised meningomyelitis. ${ }^{34}$ Herpes simplex virus is neurotropic and has been isolated from trigeminal, vagal, superior cervical, and sacral ganglions. $^{5}$

The use of bethanechol chloride in the second patient greatly helped to relieve his urinary difficulties and probably obviated the need for catheterisation. Bethanechol is a parasympathomimetic agent with the muscarinic properties of acetylcholine and has not to our knowledge been used previously in this setting. Whether the use of systemic acyclovir will shorten the course of neurogenic difficulties in micturition remains to be assessed.

In cases of urethral and vulval herpes, in addition to a neuropathic cause for urinary retention, a reflex inhibition secondary to severe pain on micturition may play a part. ${ }^{3}$ Relief of pain by local or systemic measures appears to be the appropriate management of such cases.

In summary, we emphasise the need to take a full sexual history and carefully and repeatedly to search for herpes simplex virus infection of the urethra and anorectum in all young patients with urinary retention or micturition difficulties.

We thank Mr Russell Lock for permission to report the first patient and Dr Elizabeth Paice for her encouragement.

1 Quinn CT, Corey L, Chaffee RG, Schuffler MD, Brancats FP, Holmes KK. The etiology of anorectal infections in homosexual men. Am $\mathcal{F}$ Med 1981;71:395-406.

2 Goodell SS, Quinn CT, Mkrtichia E, Schuffler MD, Holmes KK, Corey L. Herpes simplex virus proctitis in homosexual men. N Engl f Med 1983;308:868-71.

3 Oates JK, Greenhouse PRDH. Retention of urine in ano-genital herpetic infection. Lancet 1978;i:691-2.

4 Caplan LR, Kleeman FJ, Berg S. Urinary retention probably secondary to herpes genitalis. N Engl f Med 1977;297:920-1.

5 Warren KG, Brown SM, Wroblewska Z, Gilden D, Koprowski H, Subak-Sharpe J. Isolation of latent herpes simplex virus from the superior cervical and vagus ganglions of human beings. $N$ Englf Med 1978;298: 1068-9.

(Accepted 17 October 1985)

Department of Genitourinary Medicine, Royal Northern Hospital, London $\mathbf{N} 7$

W ATIA, MSC, MRCP, consultant physician

Department of Rheumatology, Whittington Hospital, London N19

C SONNEX, MB, MRCP, registrar

Correspondence to: Dr Atia.

\section{Irreversible pulmonary hypertension after treatment with fenfluramine}

Pulmonary hypertension was associated with the appetite suppressant aminorex,${ }^{1}$ but attempts to induce it in animals have failed. ${ }^{2}$ Pulmonary hypertension that resolved when treatment was stopped was also described in two patients taking the anorectic agent fenfluramine. ${ }^{3}$ We report severe irreversible pulmonary hypertension in a patient treated with fenfluramine.

\section{Case report}

A 58 year old woman was referred for investigation of worsening dyspnoea and right heart failure. Examination of the heart and lungs, an electrocardiogram, and a chest $x$ ray film had been normal eight years previously when she had attended for intermittent claudication. Her weight then had been $72 \mathrm{~kg}$ and height $154 \mathrm{~cm}$. She had next been seen aged 54 complaining of exertional dyspnoea. An apical systolic murmur was noted, and an electrocardiogram showed peaked $P$ waves and an increase in right ventricular voltage. Diuretics conferred some benefit Between the ages of 46 and 56 she received seven one month courses of fenfluramine and her maximum weight was $80.5 \mathrm{~kg}$. She had smoked 20 cigarettes a day for over 20 years.

On examination she weighed $68.5 \mathrm{~kg}$ and was peripherally and centrally cyanosed. Blood pressure was $140 / 90 \mathrm{~mm} \mathrm{Hg}$, and her jugular venous pressure was raised above the angle of the jaw. There was a parasternal lift and a grade $3 / 6$ pansystolic murmur maximal at the lower end of the sternum. She had pulsatile hepatomegaly and peripheral oedema, and the lungs were clear. An electrocardiogram showed sinus rhythm, biatrial enlargement, an axis of $+120^{\circ}$, and incomplete right bundle branch block. A chest radiograph showed a cardiothoracic ratio of 170:295; prominent hilar vessels, and clear lung fields. Routine 
biochemistry was normal, but results of liver function tests were deranged, with a bilirubin concentration of $46 \mu \mathrm{mol} / \mathrm{l}(2.7 \mathrm{mg} / 100 \mathrm{ml})$, alkaline phosphatase 265 $\mathrm{U} / \mathrm{l}$, and $\gamma$-glutamyltransferase $263 \mathrm{U} / \mathrm{l}$. Arterial blood gas tensions were: oxygen $8.0 \mathrm{kPa}(60 \mathrm{~mm} \mathrm{Hg})$, carbon dioxide $3.9 \mathrm{kPa}(29 \mathrm{~mm} \mathrm{Hg})$, bicarbonate $21 \mathrm{mmol}$ $(\mathrm{mEq}) / \mathrm{l}$, and $\mathrm{pH} 7 \cdot 45$. Haemoglobin concentration was $172 \mathrm{~g} / \mathrm{l}$. The ratio of forced expiratory volume in one second to forced vital capacity was $1 \cdot 5: 2 \cdot 43$ litre (predicted 2.0 (SD 0.4):2.0 (0.4) litres). Ventilation perfusion lung scanning showed no evidence of pulmonary embolism. Echocardiography showed an enlarged right ventricle and right atrium, paradoxical motion of the interventricular septum, but normal left sided structures. At heart catheterisation the pressures were: right atrium, atrial $22 \mathrm{~mm} \mathrm{Hg}$, ventricular $28 \mathrm{~mm} \mathrm{Hg}$ (mean $18 \mathrm{~mm} \mathrm{Hg}$ ); right ventricle $120 / 20 \mathrm{~mm} \mathrm{Hg}$; pulmonary artery $120 / 60$ (mean $75 \mathrm{~mm} \mathrm{Hg}$; aorta $140 / 80$ (mean 95 ) $\mathrm{mm} \mathrm{Hg}$; and left ventricle $140 / 0-10 \mathrm{~mm} \mathrm{Hg}$. Pulmonary capillary wedge pressure could not be obtained. Pulmonary arteria oxygen saturation was $51 \%$ and aortic $90 \%$, with no evidence of an intracardiac shunt. Cardiac index was $1.5 \mathrm{litres} / \mathrm{min} / \mathrm{m}^{2}$.

She was not grossly obese, and we did not think she had developed hypoxia from hypoventilation. She did not give a history of chronic bronchitis, results of pulmonary function tests were normal, and she had only mild hypoxaemia Severe primary pulmonary hypertension was diagnosed. She was electively readmitted for invasive monitoring of pulmonary artery pressure and acute drug testing. High flow oxygen $(60 \%)$, nifedipine, captopril, hydralazine, and isoprenaline failed to produce a beneficial effect. As anticoagulation improves survival in primary pulmonary hypertension ${ }^{4}$ warfarin was started. She died suddenly several months later. At necropsy there was appreciable right ventricular dilatation and hypertrophy. Histological examination of the lungs showed the changes of florid classical plexogenic pulmonary hypertension with no evidence of thromboembolic disease or chronic bronchitis.

\section{Comment}

Pulmonary hypertension has been reported previously in two patients taking fenfluramine. ${ }^{3}$ The pulmonary hypertension was of moderate severity $(50 / 20$ and $50 / 28 \mathrm{~mm} \mathrm{Hg}$ ) and resolved completely on withdrawal of the drug. Gaul et al subsequently described pulmonary hypertension $(98 / 45 \mathrm{~mm}$ $\mathrm{Hg}$ ) in a 53 year old woman treated three years previously with fenfluramine; nifedipine considerably reduced the pressure. ${ }^{5}$ Severe and intractable pulmonary hypertension, which may be irreversible, may result from fenfluramine treatment.

We thank Dr David Lamb and Dr William Stockwell for analysing necropsy material and Dr Alexander Lawson for permission to report this case.

1 Gurtner HP, Gertsch M, Salzmann C, Sherrer M, Stucki P, Wyss F. Häufen sich die primär vasculären Formen des chronischen Cor pulmonale? Schweiz Med Wochenschr 1968;98:1579-89, vascularen 1695 .

2 Will JA, Bisgard GE. Haemodynamic effects of oral aminorex and amphetamine in unanaesthetized beagle dogs. Thorax 1972;27:120-31.

3 Douglas JG, Munro JF, Kitchin AH, Muir AL, Proudfoot AT. Pulmonary hypertension and fenfluramine. BrMed $\mathcal{F} 1981 ; 283: 881-3$.

4 Fuster V, Steele PM, Edwards WD, Gersh BJ, McGoon MD, Frye RL. Primary pulmonary hypertension - natural history and the importance of thrombosis. Circulation 1984;70:580-7.

5 Gaul G, Blazek G, Deutsch E, Heeger H. Ein Fall von chronischer pulmonaler Hypertonie nach Fenfluramineinnahme. Wein Klin Wochenschr 1982;94:618-22.

(Accepted 28 October 1985)

\section{Royal Infirmary, Edinburgh EH3 9YW}

J MCMURRAY, MB, CHB, senior house officer

P BLOOMFIELD, MRCP, registrar

H C MILLER, FRCPED, consultant cardiologist

Correspondence to: Dr Bloomfield.

\section{Hazards for elderly people admitted for respite ("holiday admissions") and social care ("social admissions")}

Sheldon in 1948 suggested the use of short stay hostels to support the carers of disabled elderly people. ${ }^{\prime}$ Since then various other schemes using different periods of admission to achieve the same aim have been developed. Though the duration of stay and intervals between admissions may vary, nearly all studies suggest that hospital beds should be used. This is despite the fact that admission to hospital is associated with appreciable mortality and morbidity. ${ }^{2}$ The purpose of this study was to look at the incidence of illness and death during the first arranged admission for respite care. As patients admitted for social care (so called "social admissions") are also free of acute illness we decided to look at this group also.

\section{Patients, methods, and results}

We analysed the medical records of all patients admitted as "holiday" or social admissions during July 1980 to February 1985. A holiday admission was defined as an elective admission arranged to give the carer a break. A social admission was defined as an unplanned admission in which no medical or rehabilitation cause was found. The diagnosis of social admission was made not only initially by the admitting doctor but also at the time of discharge. A total of 112 patients were admitted with these two diagnoses. The table gives details of age, sex ratio, occurrence of adverse events, and outcome in these patients.

The principal diagnoses in the group admitted for respite care were dementia in 28 cases, cerebrovascular disease in 24 , Parkinson's disease in six, amputation in three, other diseases in seven, and a combination of these conditions in one.

\section{Comment}

These findings show that elderly people admitted for respite care or for social reasons suffer a very high morbidity and mortality-exceeding even the $8.9 \%$ recorded for mortality among the elderly admitted with acute illness (over the age of 85 ) to our geriatric wards. ${ }^{3}$

Why do so many of these elderly people who do not have acute medical problems die shortly after admission to hospital? Is this high mortality related to disability, to the treatment they receive, or to the move from home to hospital? It is difficult to answer these questions, as there are no data on these particular groups. Data on institutionalisation of the elderly, however, may help. Many studies on institutionalisation of disabled elderly people ${ }^{45}$ clearly show a substantial early death rate, particularly within the first three months, suggesting that the move itself from a familiar setting may be important. The mortality is higher in men and in those with chronic brain syndrome, severe physical dependence, and incontinence.

Clinical details and outcome for patients admitted for respite care (holiday admissions) and social reasons

\begin{tabular}{|c|c|c|}
\hline & Holiday admissions & Social admissions \\
\hline No of patients & 69 & 43 \\
\hline Mean age in years $(\mathrm{SD})$ & $82(7 \cdot 9)$ & $85(5 \cdot 0)$ \\
\hline Sex ratio $(M: F)$ & $1: 2 \cdot 0$ & $1: 1 \cdot 7$ \\
\hline \multicolumn{3}{|l|}{ Outcome: } \\
\hline Death & 9* & $15 t$ \\
\hline Long stay & 5 & 4 \\
\hline Transfer to part III & 0 & 2 \\
\hline Transfer to psychogeriatric ward & 0 & 1 \\
\hline Discharged home & 55 & 21 \\
\hline \multicolumn{3}{|l|}{ Minor adverse events: } \\
\hline Infections & 5 & 1 \\
\hline Falls & 2 & 1 \\
\hline
\end{tabular}

*Cause of death bronchopneumonia in all cases.

tCause of death bronchopneumonia in 13 patients, left ventricular failure in one, cerebrovascular accident in one.

Whatever the reason or reasons for the high mortality, plainly even a temporary move for a short period is not without risk for the elderly. At present there are various schemes for providing short term relief-for example, so that carers may go shopping-and we must look for a means of providing prolonged periods of care at home to relieve relatives. Admission to hospital, which has been and still is readily accepted by doctors, relatives, and community workers as a solution to a social problem, must be discouraged.

1 Sheldon JH. The social medicine of old age. London: Oxford University Press, 1948:197.

2 Steel K, Gertman PM, Crescenzi C, Anderson J. Iatrogenic illness on a general medical service at a university hospital. $N$ Engl f Med 1981;304:638-42.

Rai GS, Murphy P, Pluck RA. Who should provide hospital care of the elderly people? Lancet 1985; ;:683-5.

4 Comargo O, Preston GH. What happens to patients who are hospitalized for the first time when over sixty-five years of age. Am $\mathcal{F}$ Psychiatry 1945;102:168-73.

5 Lieberman MA. Relationship of mortality rates to entrance to a home for the aged. Geriatrics 1961;16:515-9.

(Accepted 25 October 1985)

Whittington Hospital, London N19 5NF

G S RAI, MD, MRCP, consultant physician, senior lecturer

C BIELAWSKA, MB, MRCP, senior registrar

P J MURPHY, MB, MRCP, senior research fellow, locum consultant physician

G WRIGHT, MB, MRCP, lecturer, honorary senior registrar

Correspondence to: Dr Rai. 